\title{
Aquatic insect assemblages in four urban lakes of Bogor, West Java, Indonesia
}

\author{
WAKHID $^{1, \vartheta}$, AUNU RAUF ${ }^{2, v \varphi}$, MAJARIANA KRISANTI ${ }^{3,}$, I MADE SUMERTAJAYA ${ }^{4}$, NINA MARYANA ${ }^{2}$ \\ ${ }^{1}$ Program of Entomology, Graduate School, Institut Pertanian Bogor. Jl. Meranti, Kampus IPB Darmaga, Bogor 16680, Indonesia. \\ Tel.: +62-251-8629354, Fax.: +62-251-8629352, `email: wakhid.doank@yahoo.com \\ ${ }^{2}$ Department of Plant Protection, Faculty of Agriculture, Institut Pertanian Bogor. J1. Meranti, Kampus IPB Darmaga, Bogor 16680, Indonesia. \\ Tel.: +62-251-8629354, 8629350, Fax.: +62-251-8629352, ^vemail: aunu@indo.net.id \\ ${ }^{3}$ Department of Aquatic Resources Management, Faculty of Fisheries and Marine Sciences, Institut Pertanian Bogor. Jl. Agatis, Kampus IPB Darmaga, \\ Bogor 16680, Indonesia \\ ${ }^{4}$ Department of Statistics, Faculty of Mathematics and Natural Sciences, Institut Pertanian Bogor. Jl. Meranti, Kampus IPB Darmaga, Bogor 16680, \\ Indonesia
}

Manuscript received: 20 April 2020. Revision accepted: 14 June 2020.

\begin{abstract}
Wakhid, Rauf A, Krisanti M, Sumertajaya IM, Maryana N. 2020. Aquatic insect assemblages in four urban lakes of Bogor, West Java, Indonesia. Biodiversitas 21: 3047-3056. Urban lakes represent important habitats for some freshwater organisms and support a high diversity of insect fauna. Study was conducted with the objectives to determine and compare aquatic insect assemblages in four urban lakes of Bogor, West Java, Indonesia. Insects were collected in the littoral zone using D-net at a certain interval along the perimeter of each lake. Sampling was carried out monthly during March, April, and May 2017. A total of 6,686 individuals representing 82 species/morphospecies, 28 families, and seven orders were recorded. Estimation of species richness by Chao1 suggested that sampling completeness for Situ Babakan, Situ Burung, Situ Gede, and Situ Tonjong were 88.71\%, 75.86\%, 82.17\%, and 95.23\%, respectively. Rarefaction curves indicated that more sampling would record a higher species richness. The least species richness and diversity of aquatic insect assemblages occurred in Situ Babakan characterized by high organic pollution due to fish farming. Canonical correspondence analysis showed that certain environmental factors were related to some species. Chironomus sp. (Diptera: Chironomidae), Micronecta ludibunda (Hemiptera: Micronectidae), and Anisops bouvieri (Hemiptera: Notonectidae) were associated with organically polluted water. Odonates such as Pseudagrion sp.1 (Coenagrionidae), Rhinocypha sp. (Chlorocyphidae), Acisoma panorpoides, Orthetrum sabina (Libellulidae), and Crocothemis servilia (Libellulidae) were associated with conditions of a high density of macrophytes. Our study provides baseline data for future monitoring and conservation management of these lakes.
\end{abstract}

Keywords: Biodiversity, community structure, conservation, lentic, species richness

\section{INTRODUCTION}

In urban landscapes, small lakes (locally called situ) represent important habitats for some freshwater organisms and play an important role in maintaining regional biodiversity. These small lakes are home to great biodiversity of insect fauna. Shallow aquatic habitats such as small lakes are particularly vulnerable to impacts from anthropogenic inputs, and this poses a serious threat to the biodiversity of the systems which, in the case of small lakes, are considered to support a high richness of macroinvertebrates, including aquatic insects (Oertli et al. 2002). Ponds and small lakes are numerous across many landscapes (Downing et al. 2006). They form networks essential to the metapopulations of many species and provide important ecological, social, and economic services such as wildlife habitat, livestock watering, fish production or recreational activities (Jeffries 2005).

Although aquatic insects make up only six percent of all insect species, they are taxonomically diverse (Dijkstra et al. 2014). They play an important ecological role in keeping freshwater ecosystems functioning properly, including recycling of nutrients and are an essential component of the food web in aquatic ecosystems (Hadicke et al. 2017). Aquatic insects are among the most important components of freshwater ecosystems biota (Peiro et al. 2015). In addition to this significant ecosystem function, aquatic insects are very good indicators of human impact on the freshwater ecosystem. The insect orders Ephemeroptera, Plecoptera, and Trichoptera are the pollution sensitive groups and are used extensively for aquatic insect biomonitoring programs (Jacobus et al. 2019; Morse et al. 2019; Andrade et al. 2020).

Currently, there are 96 small freshwater urban lakes in the area of Bogor, West Java. Freshwaters are the most threatened ecosystems (Rosset et al. 2012). This is particularly true for ponds and small lakes, which are threatened by habitat loss, excessive nutrient load, chemical pollution, and invasion by alien species (Fenoglio et al. 2016). Considering the increasing degradation of small lakes due to anthropogenic disturbances, the search for an understanding of the ecological patterns and process operating on these lakes persists (Mabidi et al. 2017). In Indonesia, studies on the abundance and diversity of aquatic insects focused mainly on lotic ecosystems, while relatively very few works deal with the invertebrate fauna of lentic freshwater habitats, despite their great diversity and abundance in these systems. 
There are four lakes located not far from the IPB University campus: Situ Babakan, Situ Burung, Situ Gede, and Situ Tonjong. These four lakes are subject to varying degrees of anthropogenic disturbances mainly fish farming. The most intensive fish farming activities occurred in Situ Babakan. The lakes also showed varying degrees of density of aquatic macrophytes. Situ Burung and some sites of Situ Gede are characterized by a higher density of macrophytes. Hence, the objectives of this study were to investigate and compare species assemblages of aquatic insects inhabiting these four lakes through different attributes like species composition, richness, and diversity.

\section{MATERIALS AND METHODS}

\section{Study area}

The four lakes studied are located in the urban area of Bogor (Figure 1). Situ Babakan (06 31' 44.50" S, $106^{\circ} 43^{\prime}$ 41.90" E), Situ Burung (06 32' 45.30" S, $106^{\circ} 43^{\prime} 58.50^{\prime \prime}$ E), Situ Gede ( $\left.06^{\circ} 33^{\prime} 12.50^{\prime \prime} \mathrm{S}, 106^{\circ} 44^{\prime} 55.10^{\prime \prime} \mathrm{E}\right)$, and Situ Tonjong $\left(06^{\circ} 29^{\prime} 38.99^{\prime \prime} \mathrm{S}, 106^{\circ} 46^{\prime} 1.22^{\prime \prime} \mathrm{E}\right)$ have a size of 7, 2.5, 6.6, 22 ha, respectively. The lakes showed varying degrees of macrophytes and fish farming. The coverage of macrophytes along the perimeter of the lakes ranged from low (20\%) in Situ Babakan, medium (50\%) in Situ Gede and Situ Tonjong, and high (80\%) in Situ Burung. The intensity of fish farming was higher in Situ Babakan, with fish cages covering about $15-20 \%$ of the lake perimeter; while in Situ Gede and Situ Tonjong were about $5 \%$, and none in Situ Burung.

\section{Aquatic insect sampling and measurement of water physicochemical properties}

Each lake was sampled monthly in March, April, and May 2017. Aquatic insects were collected from littoral zone $(0-100 \mathrm{~cm}$ depth) by kick method whereby the vegetation and the substrate were disturbed and a D-shaped net (40 $\mathrm{cm}$ width, $400 \mu \mathrm{m}$ mesh size) was dragged around the vegetation. Five such drags constitute a sample. Sampling was carried out at a certain interval along the whole perimeter of each lake. Number of sampling sites varied 9-10, depending on the size of lakes. Insects caught on the net were filtered and separated from sludge and debris. Collected insects were immediately preserved in $90 \%$ ethanol mixed with $4 \%$ formalin with a ratio of $4: 1$. Aquatic insects were then identified up to genus or species level at the Insect Ecology Laboratory of the IPB University, with the help of identification manual and literature (Cheng et al. 2001; Nieser 2004; Yule and Yong 2004; Yang and Zettel 2005; Polhemus and Polhemus 2013).

On each sampling date, selected physicochemical properties of water such as temperature, $\mathrm{pH}$, dissolved oxygen (DO), and turbidity were recorded directly at the sampling sites. Water temperature and $\mathrm{pH}$ were measured using thermo-pH meter (ADWA AD-12), DO using DO meter (Lutron 5510), and turbidity using turbidity meter (HACH 2100Q).

\section{Data analysis}

The aquatic insect abundance and taxonomic richness were tabulated for each lake. Functional feeding groups (FFG) were classified according to Cummins (2018). Oneway analysis of variance (ANOVA) was performed to test for the significant differences of variables between the lakes using IBM SPSS Statistics version 22. The tested variables included various water quality parameters (temperature, pH, DO, turbidity) as well as insect abundance.

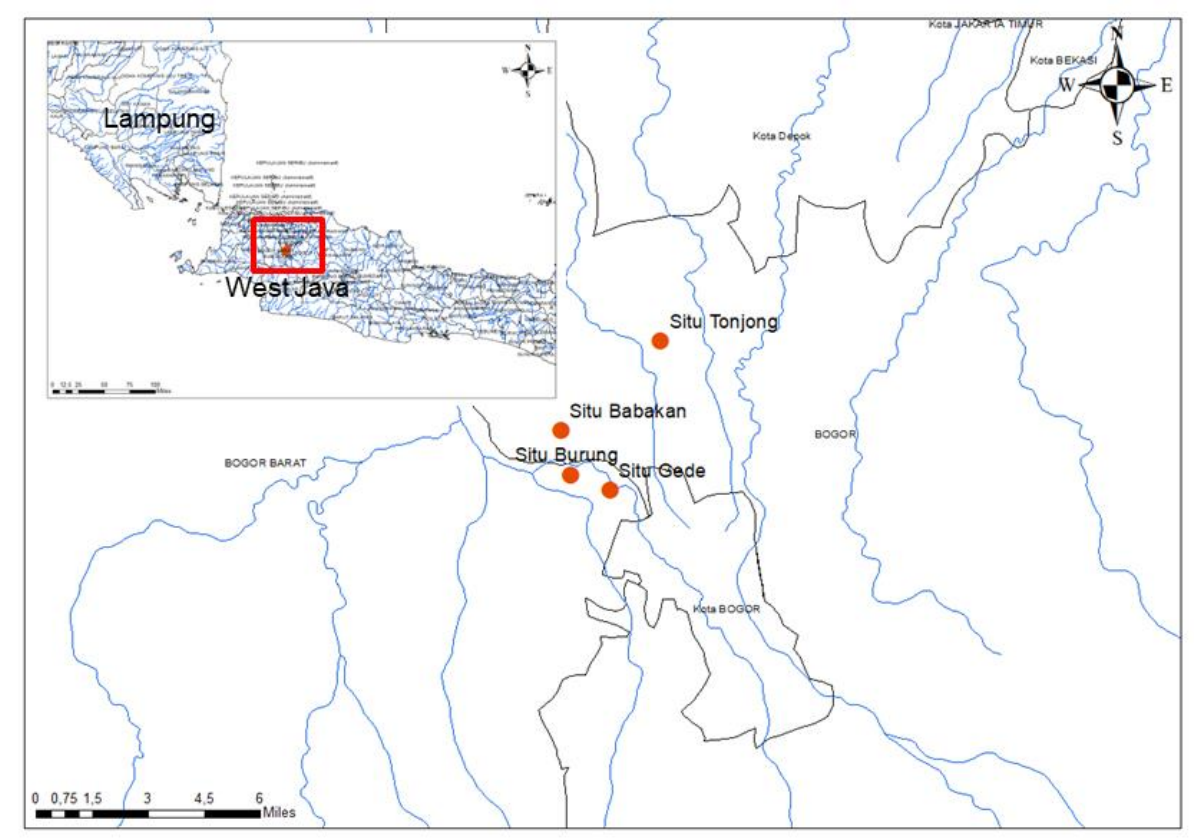

Figure 1. Map of the study area showing the locations of the four urban lakes sampled in Bogor, West Java, Indonesia 
First-order Chao (Chao1) species richness estimate was used to determine the expected number of species. According to Foggo et al. (2003), non-parametric estimate of Chao1 represents the best compromise choice of estimator for rapid estimation of species richness. Sampling completeness was calculated as the ratio of observed species richness to the species richness estimate value and expressed as a percentage. iNEXT online (Chao et al. 2016) was used to create individual-based rarefaction curves for each lake.

Data on taxonomic composition of all aquatic insects at the four lakes were subjected to diversity indices such as Shannon-Wiener $\left(H^{\prime}=-\sum p_{i} \ln p_{i}\right)$ and Simpson diversity (D$\left.{ }^{1}=1 / \sum \mathrm{p}_{\mathrm{i}}{ }^{2}\right)$, Pielou evenness $\left(\mathrm{J}=\mathrm{H}^{\prime} / \operatorname{lnS}\right)$, and Berger-Parker dominance $\left(\mathrm{d}=\mathrm{N}_{\max } / \mathrm{N}\right)$ indices (Maurer and McGill 2011; Morris et al. 2014; Veech 2018). Renyi diversity profile values $(\mathrm{H} \alpha)$ were calculated from the frequencies of each component species (pi) and a scale parameter $(\alpha)$ ranging from zero to infinity (Tothmeresz 1998) as: $\mathrm{H}_{\alpha}=(\ln$ $\left.\sum \mathrm{p}_{\mathrm{i}}\right) /(1-\alpha)$. The Renyi diversity profile is a diversity ordering technique specifically designed to rank communities from low to high diversity. At small value of the scale parameter, the Renyi diversity value is influenced by rare species; as the scale parameter increases, the diversity value is increasingly influenced by the common species. Near infinity, only the abundance of the most common species will determine the diversity (Gardener 2014).

A canonical correspondence analysis (CCA) between environmental factors (independent variables) and aquatic insect species abundance and sampling sites (dependent variables) was performed to determine the possible relationship between the distribution of aquatic insects and environmental variables. Correlations of environmental variables with the composition of the insect assemblages were tested using Monte Carlo permutations $(n=499)$. The environmental variables were physical and chemical properties of water (temperature, $\mathrm{pH}$, turbidity, DO) as well as habitat characteristics (degree of fish farming and macrophytes). This analysis was performed using PAST 2.17 (Hammer et al. 2001). Species with an abundance of less than $0.5 \%$ were excluded from the analyses. Data on insect abundance and water physicochemical properties were $\ln (\mathrm{x}+1)$ transformed prior to statistical analyses.

\section{RESULTS AND DISCUSSION}

\section{Environmental variables}

A summary of water physicochemical properties and habitat characteristics of the four lakes is presented in Table 1. ANOVA revealed significant differences of water temperature $\left(\mathrm{F}_{3}, \quad 35=3.217 ; \mathrm{P}=0.034\right)$, water $\mathrm{pH} \quad\left(\mathrm{F}_{3}\right.$, $\left.{ }_{35}=23.898 ; \mathrm{P}<0.001\right), \mathrm{DO}\left(\mathrm{F}_{3},{ }_{35}=9.109 ; \mathrm{P}<0.001\right)$, and turbidity $\left(\mathrm{F}_{3,35}=17.603 ; \mathrm{P}<0.001\right)$ between lakes. The mean value of water temperature showed little variation among lakes, with a relatively high $\left(30.36^{\circ} \mathrm{C}\right)$ in Situ Babakan and low $\left(28.44^{\circ} \mathrm{C}\right)$ in Situ Gede. The highest value of $\mathrm{pH}(8.04)$ was in Situ Tonjong while the lowest value (6.85) was recorded in Situ Burung. Dissolved oxygen (DO) was the highest $(6.57 \mathrm{mg} / \mathrm{L})$ in Situ Tonjong and the lowest (4.55) in Situ Gede. Turbidity value varied with the lowest (7.97 NTU) in Situ Babakan and the highest (21.82 NTU) in Situ Gede. Situ Babakan has the lowest score (1) for macrophytes, but the highest (2) for fish farming (Table 1). Conversely, Situ Burung has the highest score (3) for macrophytes, but the lowest (0) for fish farming.

\section{Aquatic insect fauna}

A total of 6,868 specimens representing 82 species/morphospecies belonging to 28 families and 7 orders were collected from four lakes in the present study (Table 2). Insects belonging to orders Odonata (40.24\%) showed higher species richness, followed by those belonging to Hemiptera (23.17\%), Coleoptera (20.73\%), Ephemeroptera (3.66\%), Trichoptera (2.44\%), and Lepidoptera (1.22\%). However, in term of numerical abundance, members of the order Hemiptera (39.96\%) dominated specimens collected, followed by Diptera (24.59\%), Odonata (20.72\%), Ephemeroptera (8.59\%), Coleoptera $(6.08 \%)$, Trichoptera $(0.03 \%)$, and Lepidoptera $(0.03 \%)$. Similar proportion of those insect orders have been reported for lakes and ponds outside Indonesia, such as India (Abhijna et al. 2013; Majumder et al. 2013), Ivory Coast, West Africa (Yapo et al. 2013), and Argentina (Fontanarrosa et al. 2013). Overall, mean abundance of aquatic insects in Situ Babakan (20.83 individuals per 5 $\mathrm{m}^{2}$ ), Situ Burung (20.34), and Situ Tonjong (15.48) were significantly higher $\left(\mathrm{F}_{3,35}=3.73 ; \mathrm{P}=0.02\right)$ than those in Situ Gede (5.11).

Table 1. Water physicochemical $(x \pm S E)$ and habitat characteristics of four urban lakes

\begin{tabular}{lcccc}
\hline \multicolumn{1}{c}{ Characteristics } & \multicolumn{3}{c}{ Lakes } \\
\cline { 2 - 5 } & Situ Babakan & Situ Burung & Situ Gede & Situ Tonjong \\
\hline Temperature $\left({ }^{\circ} \mathrm{C}\right)$ & $30.36 \pm 0.43 \mathrm{a}^{*}$ & $30.22 \pm 0.55 \mathrm{ab}$ & $28.44 \pm 0.47 \mathrm{~b}$ & $29.77 \pm 0.51 \mathrm{ab}$ \\
$\mathrm{pH}$ & $7.24 \pm 0.14 \mathrm{ab}$ & $6.85 \pm 0.11 \mathrm{a}$ & $7.32 \pm 0.06 \mathrm{~b}$ & $8.04 \pm 0.07 \mathrm{c}$ \\
$\mathrm{DO}(\mathrm{mg} / \mathrm{L})$ & $5.59 \pm 0.27 \mathrm{ab}$ & $6.02 \pm 0.33 \mathrm{a}$ & $4.55 \pm 0.34 \mathrm{~b}$ & $6.57 \pm 0.19 \mathrm{a}$ \\
Turbidity (NTU) & $7.97 \pm 0.51 \mathrm{a}$ & $18.23 \pm 1.74 \mathrm{bc}$ & $21.82 \pm 1.97 \mathrm{~b}$ & $16.02 \pm 1.01 \mathrm{c}$ \\
Degree of macrophytes & Low $(1)^{* *}$ & High $(3)$ & Medium $(2)$ & Medium $(2)$ \\
Degree of fish farming & High $(2)$ & None $(0)$ & Low $(1)$ & Low $(1)$ \\
\hline
\end{tabular}

Note: *Different alphabets within the same rows are significantly different at $\mathrm{p} \leq 0.05 ; * *$ number in parenthesis indicates score 
Table 2. Aquatic insects found in four urban lakes

\begin{tabular}{|c|c|c|c|c|c|c|}
\hline Order/Family/Morphospecies & FFG $^{*}$ & Situ Babakan & Situ Burung & Situ Gede & Situ Tonjong & Total \\
\hline \multicolumn{7}{|l|}{ Coleoptera } \\
\hline \multicolumn{7}{|l|}{ Curculionidae } \\
\hline Lissorhoptrus sp. & Sh & - & - & 10 & - & 10 \\
\hline \multicolumn{7}{|l|}{ Dytiscidae } \\
\hline Cybister sp. & $\operatorname{Pr}$ & - & 1 & - & - & 1 \\
\hline Dytiscidae sp. & $\operatorname{Pr}$ & - & 1 & - & - & 1 \\
\hline Dytiscus sp. & $\operatorname{Pr}$ & - & - & - & 1 & 1 \\
\hline Hyphydrus sp. & $\operatorname{Pr}$ & 2 & 13 & 4 & 23 & 42 \\
\hline Laccophilus sp. 1 & $\operatorname{Pr}$ & 14 & 7 & 1 & 18 & 40 \\
\hline Laccophilus sp.2 & $\operatorname{Pr}$ & - & 18 & 3 & 2 & 23 \\
\hline Laccophilus sp. 3 & $\operatorname{Pr}$ & - & 1 & 1 & - & 2 \\
\hline Laccophilus sp.4 & $\operatorname{Pr}$ & 1 & - & - & - & 1 \\
\hline Laccophilus sp.5 & $\operatorname{Pr}$ & - & - & - & 5 & 5 \\
\hline \multicolumn{7}{|l|}{ Gyrinidae } \\
\hline Orectochilus sp. & $\operatorname{Pr}$ & - & 14 & - & - & 14 \\
\hline \multicolumn{7}{|l|}{ Hydraenidae } \\
\hline Hydraena sp. & $\mathrm{Sc}$ & - & - & - & 5 & 5 \\
\hline \multicolumn{7}{|l|}{ Hydrophilidae } \\
\hline Amphiops mirabilis & $\mathrm{Pr}, \mathrm{GC}$ & 4 & 1 & 30 & 40 & 75 \\
\hline Helochares sp. & $\mathrm{Pr}, \mathrm{GC}$ & 12 & 78 & 15 & 72 & 177 \\
\hline Paracymus sp. & $\mathrm{Pr}, \mathrm{GC}$ & - & 1 & - & - & 1 \\
\hline Sternolophus sp. & $\mathrm{Pr}, \mathrm{GC}$ & - & 1 & - & - & 1 \\
\hline \multicolumn{7}{|l|}{ Scirtidae } \\
\hline Scirtidae sp. & Sc & - & - & - & 20 & 20 \\
\hline \multicolumn{7}{|l|}{ Diptera } \\
\hline \multicolumn{7}{|l|}{ Ceratopogonidae } \\
\hline Bezzia sp. & $\operatorname{Pr}$ & - & 1 & - & 4 & 5 \\
\hline \multicolumn{7}{|l|}{ Chironomidae } \\
\hline Chironomus sp. & GC & 715 & 388 & 63 & 344 & 1,510 \\
\hline Procladius sp. & $\operatorname{Pr}$ & 3 & 108 & - & 9 & 120 \\
\hline \multicolumn{7}{|l|}{ Culicidae } \\
\hline Anopheles sp. & $\mathrm{FC}$ & 1 & 5 & - & 7 & 13 \\
\hline Culex sp. & $\mathrm{GC}$ & 3 & - & 1 & 3 & 7 \\
\hline \multicolumn{7}{|l|}{ Tabanidae } \\
\hline Tabanidae sp. 1 & $\operatorname{Pr}$ & - & 2 & - & - & 2 \\
\hline Tabanidae sp. 2 & $\operatorname{Pr}$ & 2 & - & - & - & 2 \\
\hline \multicolumn{7}{|l|}{ Ephemeroptera } \\
\hline \multicolumn{7}{|l|}{ Baetidae } \\
\hline Baetis sp. & GC & - & 12 & - & 1 & 13 \\
\hline Cloeon sp. & $\mathrm{GC}$ & 173 & 91 & 1 & 245 & 510 \\
\hline \multicolumn{7}{|l|}{ Caenidae } \\
\hline Caenis sp. & GC & - & 78 & 11 & 36 & 125 \\
\hline Hemiptera & & & & & & \\
\hline Belostomatidae & & & & & & \\
\hline Diplonychus rusticus & $\operatorname{Pr}$ & 1 & - & 73 & 42 & 116 \\
\hline Gerridae & & & & & & \\
\hline Limnogonus fossarum & $\operatorname{Pr}$ & 3 & 18 & 8 & 29 & 58 \\
\hline Limnometra sp. & $\operatorname{Pr}$ & - & - & 11 & - & 11 \\
\hline Neogerris sp. & $\operatorname{Pr}$ & - & - & 2 & - & 2 \\
\hline Rhagadotarsus kraepelini & $\operatorname{Pr}$ & 2 & - & - & - & 2 \\
\hline Rheumatogonus sp. & $\operatorname{Pr}$ & - & 7 & - & - & 7 \\
\hline Hydrometridae & & & & & & \\
\hline Hydrometra sp. & $\operatorname{Pr}$ & - & - & - & 15 & 15 \\
\hline Mesovelidae & & & & & & \\
\hline Mesovelia $\mathrm{sp} .1$ & $\operatorname{Pr}$ & 9 & 24 & 7 & 27 & 67 \\
\hline Mesovelia $\mathrm{sp} .2$ & $\operatorname{Pr}$ & - & - & - & 9 & 9 \\
\hline Micronectidae & & & & & & \\
\hline Micronecta haliploides & $\mathrm{Sc}$ & 1 & 8 & 4 & 65 & 78 \\
\hline Micronecta ludibunda & $\mathrm{Sc}$ & 1,103 & 176 & 27 & 335 & 1,641 \\
\hline Micronecta siva & $\mathrm{Sc}$ & 11 & 8 & 5 & 35 & 59 \\
\hline Micronecta sp. & $\mathrm{Sc}$ & 5 & - & 26 & - & 31 \\
\hline
\end{tabular}




\begin{tabular}{|c|c|c|c|c|c|c|}
\hline \multicolumn{7}{|l|}{ Nepidae } \\
\hline Nepa sp. & $\operatorname{Pr}$ & - & - & - & 1 & 1 \\
\hline Ranatra gracilis & $\operatorname{Pr}$ & - & 21 & 7 & 9 & 37 \\
\hline Ranatra longipes & $\operatorname{Pr}$ & 4 & 62 & 4 & 20 & 90 \\
\hline \multicolumn{7}{|l|}{ Notonectidae } \\
\hline Anisops bouvieri & $\operatorname{Pr}$ & 249 & 36 & 19 & 16 & 320 \\
\hline Anisops kuroiwae & $\operatorname{Pr}$ & 3 & 10 & 9 & 6 & 28 \\
\hline \multicolumn{7}{|l|}{ Pleidae } \\
\hline Paraplea sp. & $\operatorname{Pr}$ & - & 38 & - & 7 & 45 \\
\hline \multicolumn{7}{|l|}{ Lepidoptera } \\
\hline \multicolumn{7}{|l|}{ Crambidae } \\
\hline Elophila sp. & Sh & - & 2 & - & - & 2 \\
\hline \multicolumn{7}{|l|}{ Odonata } \\
\hline \multicolumn{7}{|l|}{ Chlorocyphidae } \\
\hline Rhinocypha sp.1 & $\operatorname{Pr}$ & - & 100 & - & 2 & 102 \\
\hline Rhinocypha sp.2 & $\operatorname{Pr}$ & - & - & - & 1 & 1 \\
\hline \multicolumn{7}{|l|}{ Coenagrionidae } \\
\hline Agriocnemis sp. & $\operatorname{Pr}$ & 2 & 21 & 14 & 24 & 61 \\
\hline Cercion sp. & $\operatorname{Pr}$ & - & 19 & 1 & - & 20 \\
\hline Pseudagrion sp.1 & $\operatorname{Pr}$ & 10 & 394 & 4 & 127 & 535 \\
\hline Pseudagrion sp. 2 & $\operatorname{Pr}$ & - & 19 & 1 & - & 20 \\
\hline Pseudagrion sp. 3 & $\operatorname{Pr}$ & - & - & 12 & - & 12 \\
\hline \multicolumn{7}{|l|}{ Gomphidae } \\
\hline Ictinogomphus decoratus & $\operatorname{Pr}$ & 15 & 60 & 5 & 25 & 105 \\
\hline Orientogomphus armatus & $\operatorname{Pr}$ & - & 2 & - & - & 2 \\
\hline Stylurus amicus & $\operatorname{Pr}$ & - & 1 & - & - & 1 \\
\hline \multicolumn{7}{|l|}{ Libellulidae } \\
\hline Acisoma panorpoides & $\operatorname{Pr}$ & - & 29 & 3 & 4 & 36 \\
\hline Brachydiplax chalybea & $\operatorname{Pr}$ & - & 2 & 2 & - & 4 \\
\hline Brachythemis sp. & Pr & - & 1 & - & - & 1 \\
\hline Crocothemis servilia & Pr & - & 123 & 6 & - & 129 \\
\hline Libellulidae sp.1 & Pr & - & - & 3 & 8 & 11 \\
\hline Hydrobasileus croceus & Pr & - & 21 & 15 & 38 & 74 \\
\hline Libellula sp. & $\operatorname{Pr}$ & 11 & 1 & 59 & 1 & 72 \\
\hline Libellulidae sp. 2 & $\operatorname{Pr}$ & - & 1 & - & 10 & 11 \\
\hline Libellulidae sp. 3 & $\operatorname{Pr}$ & - & - & - & 2 & 2 \\
\hline Nannophya pygmaea & $\operatorname{Pr}$ & - & 27 & - & 2 & 29 \\
\hline Orthetrum sabina & $\operatorname{Pr}$ & 1 & 70 & 14 & 16 & 101 \\
\hline Orthetrum sp. & $\operatorname{Pr}$ & 1 & - & - & - & 1 \\
\hline Pantala flavescens & $\operatorname{Pr}$ & - & 1 & - & - & 1 \\
\hline Pseudothemis sp. & $\operatorname{Pr}$ & 1 & - & - & - & 1 \\
\hline Sympetrum sp.1 & $\operatorname{Pr}$ & - & - & 3 & 2 & 5 \\
\hline Sympetrum sp.2 & Pr & - & - & 1 & - & 1 \\
\hline Tholymis sp. & Pr & 5 & 2 & 3 & - & 10 \\
\hline Trithemis sp. & $\operatorname{Pr}$ & 5 & 15 & 33 & 1 & 54 \\
\hline Zyxomma obtusum & $\operatorname{Pr}$ & - & - & - & 5 & 5 \\
\hline Zyxomma sp. & $\operatorname{Pr}$ & 16 & - & 1 & 27 & 44 \\
\hline \multicolumn{7}{|l|}{ Macromiidae } \\
\hline Epopthalmia sp. & $\operatorname{Pr}$ & - & - & - & 5 & 5 \\
\hline \multicolumn{7}{|l|}{ Platycnemididae } \\
\hline Copera marginipes & $\operatorname{Pr}$ & 8 & 17 & 4 & 35 & 64 \\
\hline Platycnemis sp. & $\operatorname{Pr}$ & - & 1 & - & - & 1 \\
\hline \multicolumn{7}{|l|}{ Trichoptera } \\
\hline \multicolumn{7}{|l|}{ Hydropsychidae } \\
\hline Ceratopsyche sp. & $\mathrm{FC}$ & - & 1 & - & - & 1 \\
\hline Hydropsychidae sp. & $\mathrm{FC}$ & - & 1 & - & - & 1 \\
\hline Total abundance & & 2,396 & 2,160 & 526 & 1,786 & 6,868 \\
\hline Mean abundance per $5 \mathrm{~m}^{2}$ & & $20.83 \pm 6.28 \mathrm{a}^{* *}$ & $20.34 \pm 3.65 \mathrm{a}$ & $5.11 \pm 1.45 b$ & $15.48 \pm 1.56 \mathrm{a}$ & - \\
\hline
\end{tabular}

Mean abundance per $5 \mathrm{~m}^{2}$

$20.83 \pm 6.28 \mathrm{a} * * \quad 20.34 \pm 3.65 \mathrm{a} \quad 5.11 \pm 1.45 \mathrm{~b} \quad 15.48 \pm 1.56 \mathrm{a}$

Note: *FC: Filtering-Collectors; GC: Gathering-Collectors; Pr: Predators; Sc: Scrapers; Sh: Shredders; **Different alphabets within the same rows are significantly different at $\mathrm{p} \leq 0.05$ 
The Hemiptera was represented by 19 taxa in 13 genera and eight families: Belostomatidae, Gerridae, Hydrometridae, Mesoveliidae, Micronectidae, Nepidae, Notonectidae, and Pleidae. Micronectidae and Notonectidae were the two most common families among Hemiptera. The order Diptera was represented by at least seven genera in four families: Ceratopogonidae, Chironomidae, Culicidae, and Tabanidae. The order Odonata was represented by 30 taxa in 25 genera and six families: Coenagrionidae, Libellulidae, Chlorocyphidae, Gomphidae, Macromiidae, and Platycnemididae. At the family level, Coenagrionidae and Libellulidae dominated the collections, as also reported from other lentic habitats in India (Abhijna et al. 2013; Majumder et al. 2013) and Argentina (Fontanarrosa et al. 2013). The important member under Coenagrionidae were Pseudagrion sp. 1 in Situ Burung and Situ Tonjong, whereas under Libellulidae were Crocothemis servilia and Orthetrum sabina. The nymphs of the two families were mostly found at the edges of lakes.

The order Ephemeroptera can be found in a variety of locations including lakes, ponds, wetlands, streams, and rivers; however, they are most common and diverse in lotic habitats (Bouchard 2004). In our study, the Ephemeroptera was represented by families Baetidae and Caenidae. Some species of these families are primarily restricted to lakes and ponds (Bouchard 2004). Fontanarrosa et al. (2013) who studied aquatic insects of ponds in Argentina reported Baetidae and Caenidae as the only families representing Ephemeroptera. Studies of aquatic insects in lakes in India (Balachandran et al. 2012; Abhijna et al. 2013) and in Switzerland (Menetrey et al. 2008) reported similar results. The major aquatic Coleoptera was contributed by the families Dytiscidae and Hydrophilidae. Other important insects recorded under this order were Curculionidae, Gyrinidae, Hydraenidae, and Scirtidae. The order Lepidoptera is generally terrestrial, but there are a few species with aquatic larvae (Bouchard 2004). In our study, the Lepidoptera was represented by two specimens of Elophila sp and found only in Situ Burung. Larvae live in ponds or stagnant water, making portable cases. They are mostly polyphagous, usually feeding on floating leaves of many aquatic plants or sometimes feeding on submerged plants (Chen et al. 2010). The order Trichoptera was represented by a single specimen of Ceratopsyche sp. and Hydropsychidae sp., both found only in Situ Burung. The low incidence of Trichoptera in the studied lakes was not surprising since caddisflies are generally abundant in running (lotic) waters (Bouchard 2004).

An analysis of FFG (Table 2, column 2) based on individual number showed a relatively higher proportion of scrapers in Situ Babakan (46.7\%), followed by Situ Tonjong (25.7\%), Situ Gede (11.8\%), and Situ Burung $(8.9 \%)$. Scrapers were dominated by Micronectidae. A higher proportion of gathering-collectors was found in Situ Tonjong (41.5\%), followed by Situ Babakan (37.8\%), Situ Burung (30.1\%), and Situ Gede (23.0\%). Gatheringcollectors were dominated by Chironomus sp., Hydrophilidae, and Baetidae. Predators were higher in Situ Gede (63.3\%), as compared to Situ Burung (60.6\%), Situ
Tonjong (32.4\%), and Situ Babakan (15.4\%). Predators were dominated by Dytiscidae (Coleoptera), Notonectidae (Hemiptera), and Coenagrionidae and Libellulidae (Odonata). Overall proportions of scrapers, gatheringcollectors, predators were $26.7 \%, 35.2 \%, 37.7 \%$, respectively. Shredders and filtering-collectors were scarce and together comprised less than $0.4 \%$ of the total insects collected. Shredders were represented by Lyssorhoptrus sp. (Coleoptera: Curculionidae) and Elophila sp. (Lepidoptera: Crambidae), while filtering-collectors by larvae of Anopheles sp. (Diptera) and of Hydropsychidae (Trichoptera). Trichoptera (filtering-collectors) commonly inhabit fast-flowing water that allows them efficient by obtaining organic matter (Morse et al. 2019). Predominance of scrapers, gathering-collectors, and predators was also reported for lakes in Bulgaria (Varadinova et al. 2019). Distributions of FFGs are closely related to food resources available in the lakes. Lakes with high organic content due to anthropogenic inputs tend to support more species from gathering-collectors and scrapers FFGs. These groups, in turn, support species from the predator FFG.

\section{Species richness and diversity}

Estimation of species richness by Chao1 showed that expected species richness for Situ Tonjong was very close to the observed value (Table 3), suggesting sampling completeness reached $95.24 \%$. Sampling completeness for Situ Babakan, Situ Burung, and Situ Gede were $88.71 \%$, $75.86 \%$, and $82.17 \%$, respectively. Estimation of species richness by Chaol showed that expected species richness for each lake, especially Situ Burung, are above their observed values. The estimate of species richness for Situ Babakan, Situ Burung, Situ Gede, and Situ Tonjong were higher by $4,17,9,2$ species than the observed values, respectively. The Chaol estimator is calculated using taxa represented by singletons or doubleton specimens (Colwell and Coddington 1994; Gotelli and Chao 2013). As the number of singletons increases relative to doubletons, the estimate increases in value (Chazdon et al. 1998). Situ Burung had 15 singletons and 4 doubletons, whereas Situ Tonjong had 6 singletons and 5 doubletons. In addition, species richness will be underestimated if specimens are identified only to morphospecies because, at this level, genera may contain more than one species (Rosenberg et al. 2008). For our study, out of 82 taxa only 23 were identified to the species level, 51 to generic level, and the remaining eight to family level. Unique taxa may be undetected at the generic level or higher (McPherson et al. 2013). Therefore, the observed taxa richness may have been underestimated.

The rarefaction-extrapolation curves of each lake showed quick rises at first and then approached asymptote gently (Figure 2). The 95\% confidence interval of the curve of Situ Babakan did not overlap with that of other lakes, confirming that the species richness in Situ Babakan significantly lower than the three other lakes. Rarefactionextrapolation curves indicate that more sampling would record higher species diversity than is reported in the present study. Moreover, short term sampling did not cover 
all the species which were active in different seasons of a year, hence, the true number of species estimated for the four lakes might be higher than the predicted value.

Among the four urban lakes studied, the most abundant aquatic insects collected $(2,396)$ was from Situ Babakan. However, this lake had the lowest observed species richness (33) and smallest values of Shannon-Wiener (1.52), Simpson (3.15) and Pielou (0.43) indices, and the highest value of Berger-Parker dominance index (0.46) (Table 3). An ecosystem exhibiting a low evenness and a high dominance is one in which a few sampled species dominate (Maurer and McGill 2011; Morris et al. 2014). In the case of Situ Babakan, this undoubtedly was due to the presence of two dominant species, i.e., Micronecta ludibunda and Chironomus sp. In contrast, although the abundance of aquatic insects collected was the lowest (526), Situ Gede showed the highest Shannon (3.11) and Simpson (15.09) diversity indices, attributed to the high evenness (Pielou $\mathrm{J}=0.83$ ) and low dominance $(\mathrm{d}=0.14)$ indices. According to Wilhm (1970) Shannon-Wiener index $(\mathrm{H})$ value varies between three and four in cleanwater ecosystems and is usually less than one in polluted water ecosystems.

Diversity of the lakes was also compared by using Renyi diversity profiles (Figure 3). When using these profiles, two communities can be ranked only when their curves do not intersect (Gardener 2014). The comparison of the Renyi diversity profiles of the aquatic insect assemblages indicated that Situ Babakan was unequivocally the least diverse compared to Situ Gede, Situ Burung, and Situ Tonjong. The diversity profile for Situ Babakan is consistently below the diversity profile for the other lakes at each value of $\alpha$. In particular, measures related to species richness $(\alpha=0)$, Shannon-Wiener $(\alpha=1)$, and Simpson $(\alpha=2)$ diversity indices were always lower in Situ Babakan. The diversity profile of Situ Burung was a little above Situ Tonjong suggesting slightly more diverse, as also indicated by their Shannon-Wiener index. The diversity profile of Situ Gede intersected with those of Situ Burung and Situ Tonjong, which means that the diversity relationship between Situ Gede and either Situ Burung and Situ Babakan was not unequivocal. Situ Burung and Situ Tonjong were more diverse than Situ Gede at $\alpha<0.3$, while Situ Gede was more diverse at $\alpha>0.4$. At small values of the scale parameter, the Renyi diversity value is influenced by rare species; as the scale parameter increases, the diversity value is increasingly influenced by the common species (Tothmeresz 1998).

Table 3. Species richness and diversity indices of aquatic insects in four urban lakes of Bogor, Indonesia

\begin{tabular}{lcccc}
\hline \multicolumn{1}{c}{ Parameters } & Situ Babakan & Situ Burung & Situ Gede & Situ Tonjong \\
\hline Number of individuals & 2,396 & 2,160 & 526 & 1,786 \\
Observed species richness & 33 & 55 & 43 & 50 \\
Singleton & 7 & 15 & 8 & 6 \\
Doubleton & 4 & 4 & 2 & 5 \\
Estimated species richness (Chao1) & 37.2 & 72.5 & 52.33 & 52.5 \\
Sampling completeness (\%) & 88.71 & 75.86 & 82.17 & 95.23 \\
Shannon-Wiener diversity (H') & 1.52 & 2.93 & 3.11 & 2.83 \\
Simpson diversity (D ${ }^{-1}$ ) & 3.15 & 11.23 & 15.09 & 9.62 \\
Pielou evenness (J) & 0.43 & 0.73 & 0.83 & 0.72 \\
Berger-Parker dominance (d) & 0.46 & 0.18 & 0.14 & 0.19 \\
\hline
\end{tabular}

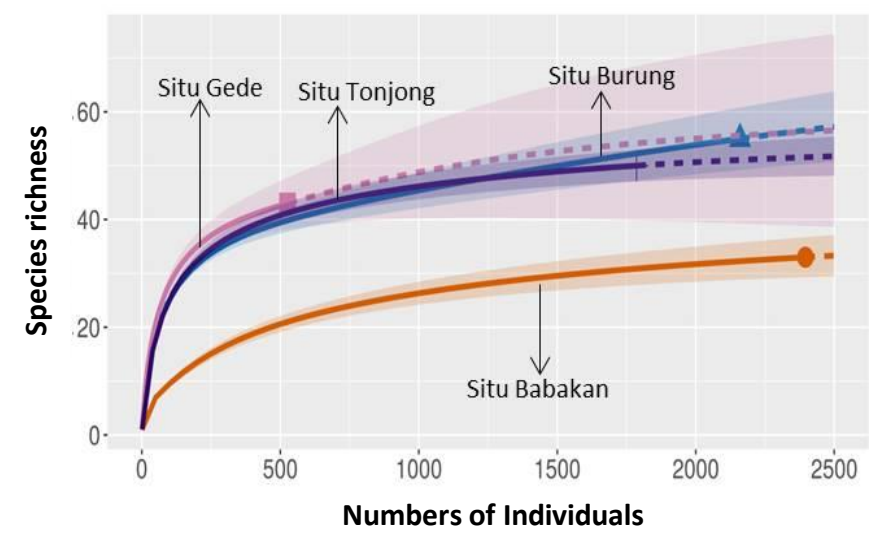

Figure 2. Individual-based rarefaction curves for the four urban lakes (data: solid lines, extrapolation: dashed line). Shaded areas indicate $95 \%$ confidence intervals

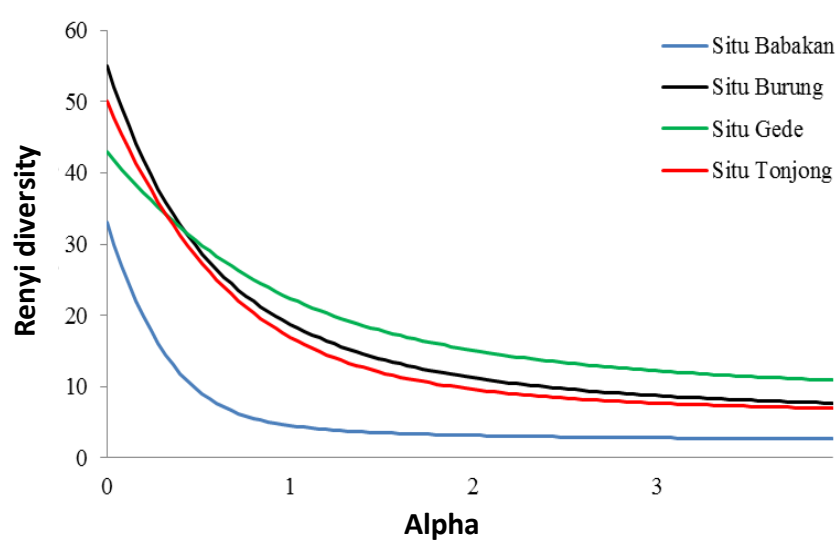

Figure 3. Renyi diversity profiles for aquatic insect assemblages in four urban lakes 


\section{Relationship with environmental variables}

The canonical correspondence analysis showed that ordination axes 1 and 2 explain $41.3 \%$ (eigenvalue $=0.1902$; $\mathrm{P}=0.002$, Monte Carlo permutation test) and $28.1 \%$ (eigenvalue $=0.1213 ; \mathrm{P}=0.002$ ), respectively, of the total variation on the abundance of aquatic insects (Figure 4). Fish farming was positively associated with axis 1 (score: 0.683 ), whereas macrophytes and turbidity negatively associated with axis 1 (scores: -0.795 and -0.369 , respectively). DO negatively associated with axis 2 (scores: -0.408). The scores on axis 1 (horizontal) clearly separated the most organically-polluted lake (Situ Babakan) from the less polluted lake (Situ Burung). Axis 1 also separated lake with dense macrophytes (Situ Burung) from the lakes with less dense macrophytes.

Among species common in the most polluted lake was a dipteran Chironomus sp. The abundance of Chironomus sp. was associated with a high organic matter present in the lake as a result of fish farming (Figure 4). Chironomids commonly possess the dominant status at the expense of other sensitive groups ( $\mathrm{Li}$ et al. 2010). Most of the species are able to tolerate very low oxygen conditions (Lencioni et al. 2012; Serra et al. 2017; Molineri et al. 2020). In freshwater ecosystems, Chironomidae are currently considered indicators of poor water quality because the family is often abundant in degraded sites (Serra et al. 2017). The high abundance of Chironomus sp. in Situ Babakan might indicate that this water body is highly eutrophic.
Other common species found in the polluted lake were three hemipterans: M. ludibunda, Micronecta siva, and Anisops bouvieri. The high abundance of M. ludibunda was related to the abundance of decaying organic matter and algae, as a result of fish farming. Fernando and Leong (1963) found enormous numbers of M. ludibunda in highly polluted fishponds, artificially fertilized with animal feces. This is due largely to their unique mode of feeding, namely the ability to ingest detritus from the bottom ooze. Algae form the main component of the diet and consist of desmids, diatoms and various filamentous green and bluegreen algae (Hadicke et al. 2017). The insect can ingest the algae whole or extract the cell contents by suction. Micronecta siva was also found abundant in rice fields in Bogor (Wakhid et al. 2020). The abundance of $A$. bouvieri might be associated with the abundance of various preys. The insect feeds voraciously on fish fry, larvae, and nymphs of other aquatic insects and different types of planktonic crustaceans (Sano et al. 2011; Domingos and Arcifa 2017). Many species of backswimmer have a strong preference for mosquito larvae (Weterings et al. 2014). The abundance of $A$. bouvieri in our study might be related to the abundance of its prey such as chironomid larvae. Most aquatic hemipterans do not rely heavily on dissolved oxygen in the water, but instead, obtain oxygen from the atmosphere. Due to their ability to utilize atmospheric oxygen, Hemiptera is often able to exist in water bodies with low levels of dissolved oxygen (Bouchard 2004).

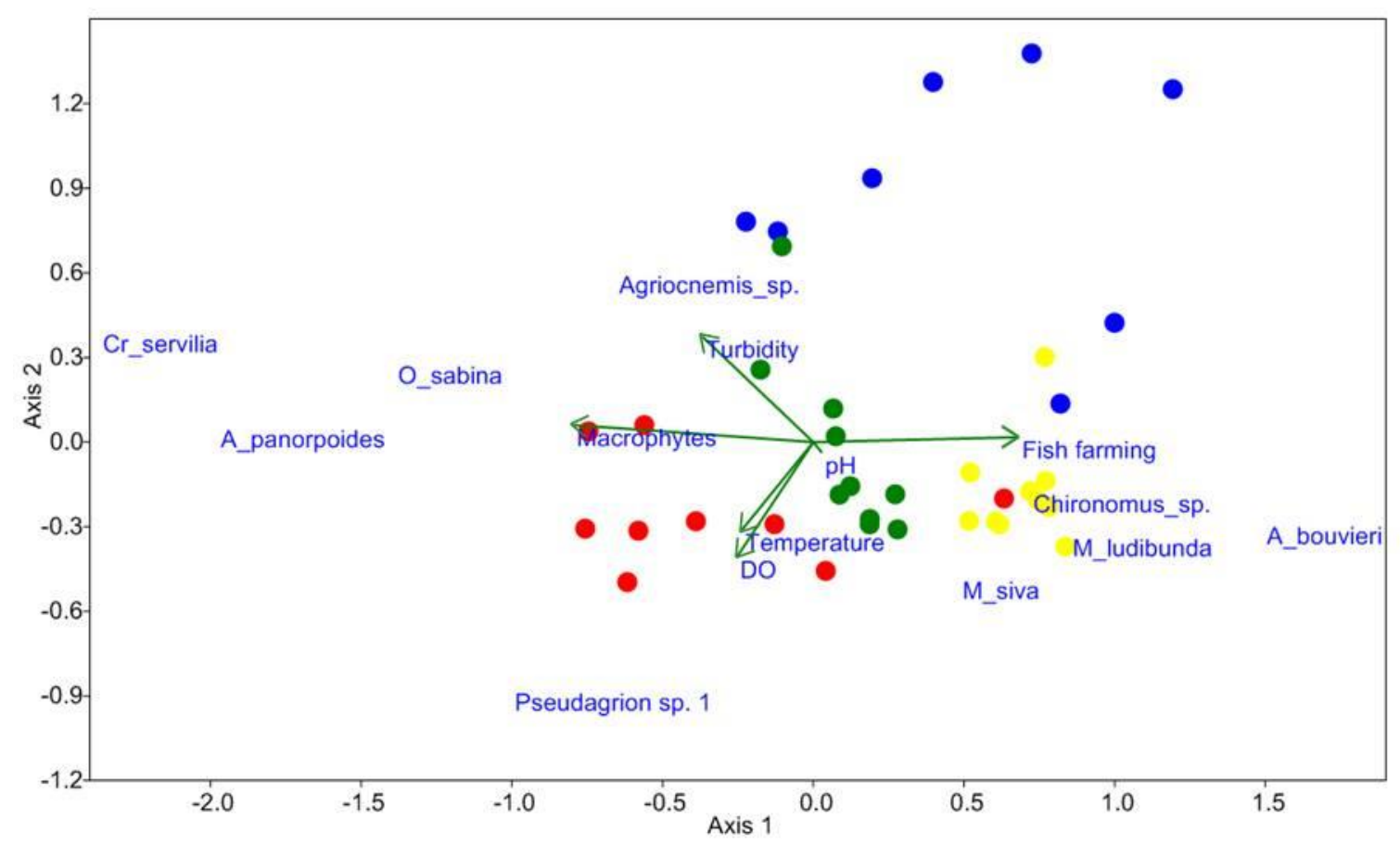

Figure 4. CCA ordination of aquatic insect assemblages in four urban lakes in relation to environmental variables. Some species are not labelled to avoid congested graph. Dots represent sampling sites: $:$ Situ Babakan, $\bullet$ : Situ Gede, $\bullet$ : Situ Tonjong, $\bullet$ : Situ Burung 
Diversity and abundance of aquatic insects are also often influenced by the presence of aquatic macrophytes. Aquatic insects commonly found in the lakes with dense macrophytes were dragonflies Acisoma panorpoides, $C$. servilia and $O$. sabina, and damselflies Rhinocypha sp. and Pseudagrion sp. 1 (Figure 4). In this regard, Situ Burung supported the highest richness and abundance of odonates. Damselflies are obligate endophytic and use a variety of aquatic plants within which to lay their eggs (stems and leaves) (Butler and deMaynadier 2008). It has been reported that higher abundance and diversity of aquatic insects were found in ponds with extensive macrophyte, and conversely, the one with no littoral vegetation had the lowest number of insect taxa and diversity of aquatic insects (Fontanarossa et al. 2013). The aquatic vegetation provide habitat, food resources, refuge from predators, and structure for mating and emergence of aquatic insects which contribute to the wealth of aquatic invertebrate biodiversity (Peiro et al. 2015).

\section{Implication of the study for conservation}

The findings presented here provide the first account of the aquatic insect assemblages in small lakes in the region of Bogor. This study has demonstrated that small lakes support rich faunal communities of potentially high conservation value in rural and urban settings. The loss of biodiversity has become a major concern globally. Until recently, the most widely used and comprehensive conservation assessments have been disproportionally focused on vertebrates, especially large terrestrial mammals (Ceballos et al. 2017). However, the highest extinction risk and therefore greatest loss of biodiversity is expected to be suffered by invertebrates, specifically insects (Harvey et al. 2020). Since invertebrates are more specious than vertebrates and in most cases less well known, knowledge of the threat status of invertebrates is limited, and therefore rarely considered in measures of global biodiversity change (Clausnitzer et al. 2017).

Freshwater is among the most threatened ecosystem worldwide (WWF 2016). This is particularly true for ponds and small lakes which are threatened by habitat loss, excessive nutrient load, and chemical pollution (Rosset et al. 2012; Sueyoshi et al. 2016; Fenoglio et al. 2016). To these threats should also be added the drastic diminution of the number of lakes, as the consequence of infilling (both natural and caused by direct habitat destruction), land drainage, and changes of function. The rate of decline of biodiversity in some freshwater systems is estimated to be five times greater than in terrestrial counterparts (Dudgeon 2010). Sanchez-Bayo and Wyckhuys (2019) reported that four major aquatic taxa (Odonata, Plecoptera, Trichoptera, Ephemeroptera) have already lost a considerable proportion of species over recent years.

Various studies suggest that ponds and small lakes may be particularly important for maintaining urban freshwater biodiversity (Hill et al. 2016; Oertli and Parris 2019). Numerous lakes (situ) in Bogor are unprotected and under strong anthropogenic threats. The incorporation of such lakes into the conservation units would be a strong way to conserve aquatic biodiversity (Maltchik et al. 2012).
Rehabilitation of lakes coupled with reducing the contamination by runoff and leaching of toxic chemicals, particularly pesticides, should be given priority for the recovery of freshwater biodiversity (Sanchez-Bayo and Wyckhuys 2019).

In conclusion, the current study provides insights into the aquatic insect assemblages of the urban lakes of Bogor, and serves as a baseline for monitoring future trends of the aquatic insect communities and for evaluating conservation and management effort over time. Overall, this paper represents a first step towards the knowledge on assemblage structure and diversity patterns of aquatic insects of urban lakes in Indonesia. More field studies on different freshwater habitats and regions are needed.

\section{ACKNOWLEDGEMENTS}

This work was supported by the Ministry of Research, Technology, and Higher Education of the Republic of Indonesia through PMDSU scholarship program.

\section{REFERENCES}

Abhijna UG, Ratheesh R, Kumar AB. 2013. Distribution and diversity of aquatic insects of Vellayani lake in Kerala. J Environ Biol 34 (3): 605-611.

Andrade ICP, Krolow TK, Boldrini R, Pelicice FM. 2020. Diversity of EPT (Ephemeroptera, Plecoptera, Trichoptera) along streams fragmented by waterfalls in the Brazilian Savanna. Neotrop Entomol 403: $203-212$

Balachandran C, Dinakaran S, Alkananda B, Boominathan M, Ramachandra TV. 2012. Monitoring aquatic macroinvertebrates as indicators for assessing the health of lakes in Bangalore, Karnataka. Intl J Adv Life Sci 5 (1): 19-33.

Bouchard RW. 2004. Guide to Aquatic Invertebrates of the Upper Midwest. Water Resources Center, University of Minnesota, St Paul.

Butler RG, deMaynadier PG. 2008. The significance of littoral and shoreline habitat integrity to the conservation of lacustrine damselflies (Odonata). J Insect Conserv 12: 23-36.

Ceballos G, Ehrlich PR, Dirzo R. 2017. Biological annihilation via the ongoing sixth mass extinction signalled by vertebrate population losses and declines. Proc Natl Acad Sci USA 114 (30): E6089-E6096.

Chao A, Ma KH, Hsieh TC. 2016. iNEXT (iNterpolation and EXTrapolation) Online: Software for Interpolation and Extrapolation of Species Diversity. Program and User's Guide. http://chao.stat.nthu.edu.tw/wordpress/software_download/.

Chazdon RL, Colwell RK, Denslow JS, Guariguata MR. 1998. Statistical methods for estimating species richness of woody regeneration in primary and second rain forests of Northeastern Costa Rica. In: Dallmeier F, Comoskey JA (eds) Forest Biodiversity Research, Monitoring and Modeling. Conceptual Background and Old World Case Studies. The Parthenon Publishing Group, Paris.

Chen F, Wu Ch, Xue D. 2010. A review of the genus Elophila Hubner, 1822 in China (Lepidoptera: Crambidae: Acentropinae). Aquat Insect 32 (1): 35-60.

Cheng L, Yang CM, Andersen NM. 2001. Guide to the aquatic Heteroptera of Singapore and Peninsular Malaysia I. Gerridae and Hermatobatidae. Raffles B Zool 49 (1): 129-148.

Clausnitzer V, Simaika JP, Samways MJ, Daniel BA. 2017. Dragonflies as flagship for sustainable use of water resources in environmental education. Appl Env Edu Comm 16 (3): 196-209.

Colwell RK, Coddington JA. 1994. Estimating terrestrial biodiversity through extrapolation. Phil Trans R Soc Lond B Biol Sci 345: 101-118.

Cummins KW. 2018. Functional analysis of stream macroinvertebrates. Limnology: Some New Aspects of Inland Water Ecology. IntechOpen, London.

Dijkstra KDB, Monaghan MT, Pauls SU. 2014. Freshwater biodiversity 
and aquatic insect diversification. Annu Rev Entomol 59 (1): 143-163.

Domingos AR, Arcifa MS. 2017. Distribution and fluctuations of backswimmers (Notonectidae) in a tropical shallow lake and predation on microcrustaceans. Braz J Biol 77 (1): 108-117.

Downing JA, Prairie YT, Cole JJ, Duarte CM, Tranvik L, Striegel RG, McDowell WH, Kortelainen P, Caraco NF, Melack JM, Middlebur JJ. 2006. The global abundance and size distribution of lakes, ponds and impoundments. Limnol Oceanogr 51 (5): 2388-2397.

Dudgeon D. 2010. Prospects for sustaining freshwater biodiversity in the $21^{\text {st }}$ century: Linking ecosystem structure and function. Curr Opin Env Sust 2 (5-6): 422-430.

Fenoglio S, Bonada N, Guareschi S, Lopez-Rodriguez MJ, Millan A, Tierno de Figueroa JM. 2016. Freshwater ecosystems and aquatic insects: a paradox in biological invasions. Biol Lett 12 (4): 1-4.

Fernando CH, Leong CY. 1963. Miscellaneous notes on the biology of Malayan Corixidae (Hemiptera: Heteroptera) and a study of the life histories of two species, Micronecta quadristrigata Bredd. and Agraptocorixa hyalinipennis (F.). J Nat His 69: 545-558.

Foggo A, Attrill MJ, Frost MT, Rowden AA. 2003. Estimating marine species richness: An evaluation of six extrapolative techniques. Marine Ecol Prog Ser 248: 15-26.

Fontanarrosa M, Collantes M, Bachmann A. 2013. Aquatic insect assemblages of man-made permanent ponds, Buenos Aires City, Argentina. Neotrop Entomol 42 (1): 22-31.

Gardener M. 2014. Community Ecology: Analytical Methods Using R and Excel. Pelagic Publishing, Exeter.

Gotelli NJ, Chao A. 2013. Measuring and estimating species richness, species diversity, and biotic similarity from sampling data. In: Levin SA (eds) Encyclopedia of Biodiversity. Academic Press, Waltham.

Hadicke CW, Redei D, Kment P. 2017. The diversity of feeding habits recorded for water boatmen (Heteroptera: Corixoidea) world-wide with implications for evaluating information on the diet of aquatic insects. European J Entomol 114: 147-159.

Hammer O, Harper DAT, Ryan PD. 2001. PAST: Paleontological statistics software package for education and data analysis. Palaeontol Electron 4 (1): 1-9.

Harvey JA, Heinen R, Armbrecht I, Basset Y, Baxter-Gilbert JH, Bezemer TM, Böhm M, Bommarco R, Borges PAV, Cardoso P, Clausnitzer V, Cornelisse T, Crone EE, Dicke M, Dijkstra KDB, Dyer L, Ellers J, Fartmann T, Forister ML, Furlong MJ, Garcia-Aguayo A, Gerlach J, Gols R, Goulson D, Habel JC, Haddad NM, Hallmann CA, Henriques S, Herberstein ME, Hochkirch A, Hughes AC, Jepsen S, Jones TH, Kaydan BM, Kleijn D, Klein AM, Latty T, Leather SR, Lewis SM, Lister BC, Losey JE, Lowe EC, Macadam CR, Montoya-Lerma J, Nagano CD, Ogan S, Orr MC, Painting CJ, Pham TH, Potts SG, Rauf A, Roslin TL, Samways MJ, Sanchez-Bayo F, Sar SA, Schultz CB Soares AO, Thancharoen A, Tscharntke T, Tylianakis JM, Umbers KDL, Vet LEM, Visser ME, Vujic A, Wagner DL, Wallis de Vries MF, Westphal C, White TE, Wilkins VL, Williams PH, Wyckhuys KAG, Zhu ZR, de Kroon H. 2020. International scientists formulate a roadmap for insect conservation and recovery. Nature Ecol Evol 4 174-176.

Hill MJ, Ryves DB, White JC, Wood PJ. 2016. Macroinvertebrate diversity in urban and rural ponds: Implications for freshwater biodiversity conservation. Biol Conserv 201: 50-59.

Jacobus LM, Macadam CR, Sartori M. 2019. Mayflies (Ephemeroptera) and their contribution to ecosystem services. Insects 10 (6): 1-26.

Jeffries M. 2005. Small ponds and big landscapes: The challenge of invertebrate spatial and temporal dynamics for European pond conservation. Aquat Conserv 15 (6): 541-547

Lencioni V, Marziali L, Rossaro B. 2012. Chironomids as bioindicators of environmental quality in mountain springs. Freshw Sci 31 (2): 525-541.

Li L, Zheng B, Liu L. 2010. Biomonitoring and bioindicators used for river ecosystems: Definition, approach and threads. Procedia Environ Sci 2: 1510-1524.

Mabidi A, Bird MS, Perissinotto F. 2017. Distribution and diversity of aquatic macroinvertebrate assemblages in a semi and arid region earmarked for shale gas exploration (Eastern Karoo, South Africa). Plos One 12 (6): e0178559. DOI: 10.1371/journal.pone.0178559.

Majumder J, Das RK, Majumder P, Ghosh D, Agarwala BK. 2013 Aquatic insect fauna and diversity in urban freshwater lakes of Tripura, North East India. Middle-East J Sci Res 13 (1): 25-32.

Maltchik L, Dalzochio MS, Stenert C, Rolon AS. 2012. Diversity and distribution of aquatic insects in Southern Brazil wetlands: Implications for biodiversity conservation in a Neotropical region. Rev Biol Trop 60 (1): 273-289.
Maurer BA, McGill BJ. 2011. Measurement of species diversity. In: Magurran AE, McGill BJ (eds.). Biological Diversity: Frontiers in Measurement and Assessment. Oxford University Press, Oxford.

McPherson JE, Turner JM, Whiles MR. 2013. Diversity and community structure of stream insects in a minimally disturbed forested watershed in Southern Illinois. Great Lakes Entomol 46: 42-83

Menetrey N, Oertli B, M. Sartori M, Wagner A, Lachavanne JB. 2008. Eutrophication: Are mayflies (Ephemeroptera) good bioindicators for ponds?. Hydrobiologia 597 (1): 125-135.

Molineri C, Tejerina EG, Torrejón SE, Pero EJI, Hankel GE. 2020. Indicative value of different taxonomic levels of Chironomidae for assessing the water quality. Ecol Indic 108: 1-7.

Morris EK, Caruso T, Buscot F, Fischer M, Hancock C, Maier TJ, Meiners T, Muller C, Obermaier E, Prati D, Socher SA, Sonnemann I, Waschke N, Wubet T, Wurst S, Rillig MC. 2014. Choosing and using diversity indices: Insights for ecological applications from the German biodiversity exploratories. Ecol Evol 4 (18): 3514-3524.

Morse JC, Frandsen PB, Graf W, Thomas JA. 2019. Diversity and ecosystem services of Trichoptera. Insects 10 (5): 1-25.

Nieser N. 2004. Guide to aquatic Heteroptera of Singapore and peninsular Malaysia III. Pleidae and Notonectidae. Raffles B Zool 52 (1): 79-96.

Oertli B, Parris KM. 2019. Review: Toward management of urban ponds for freshwater biodiversity. Ecosphere 10 (7): 1-33.

Oertli B, Joye DA, Castella E, Juge R, Cambin D, Lachavanne JB. 2002. Does size matter? The relationship between pond area and biodiversity. Biol Conserv 1004: 59-70.

Peiro DF, do Amaral GF, Saulino HHL. 2015. Structure community of aquatic insects associated with different macrophytes in ornamental lakes in a savanna region, Southeastern Brazil. Panamjas 10 (4): 273-282.

Polhemus DA, Polhemus JT. 2013. Guide to the aquatic Heteroptera of Singapore and peninsular Malaysia X. infraorder nepomorphafamilies Belostomatidae and Nepidae. Raffles B Zool 61 (1): 25-45.

Rosenberg DM, Resh VH, King RS. 2008. Use of aquatic insects in biomonitoring. In: Merritt RW, Cummins KW (eds). An Introduction to the Aquatic Insects of North America (4 ${ }^{\text {th }}$ ed). Kendall Hunt Publishing Company, Iowa.

Rosset V, Simaika JP, Arthaud F, Bornette G, Vallod D, Samways MJ, Oertli B. 2012. Comparative assessment of scoring methods to evaluate the conservation value of pond and small lake biodiversity. Aquat Conserv 23 (1): 23-36.

Sanchez-Bayo F, Wyckhuys KAG. 2019. Worldwide decline of the entomofauna: A review of its drivers. Biol Conserv 232: 8-27.

Sano K, Miyoshi K, Ishikawa S, Liepvisay N, Kurokura H. 2011. Impact of predation by water insects on fish seed production in Lao PDR. Jpn Agric Res Q 45 (4): 461-465.

Serra SRQ, Graca MAS, Doledec S, Felo MJ. 2017. Chironomidae traits and life history strategies as indicators of anthropogenic disturbance. Environ Monit Assess 189 (7): 1-16.

Sueyoshi M, Ishiyama N, Nakamura F. 2016. B-diversity decline of aquatic insects at the microhabitat scale associated with agricultural land use. Landsc Ecol Eng 12: 187-196.

Tothmeresz B. 1998. On the characterization of scale-dependent diversity. Abstr Bot 22: 149-156.

Varadinova ED, Kerakova MY, Ihtimanska MK, Soufi RA. 2019. Trophic structure of macrozoobenthos and assessment of ecological status of lakes and reservoirs in Bulgaria. Acta Zool Bulg 71 (1): 113-120.

Veech JA. 2018. Measuring biodiversity. In: Dellasala DA, Goldstein MI (eds) Encyclopedia of The Anthropocene. Elsevier, Oxford.

Wakhid, Rauf A, Krisanti M, Sumertajaya IM, Maryana N. 2020. Species richness and diversity of aquatic insects inhabiting rice fields in Bogor, West Java, Indonesia. Biodiversitas 21 (1): 34-42.

Weterings R, Vetter KC, Umponstira C. 2014. Factors influencing the predation rates of Anisops breddini (Hemiptera: Notonectidae) feeding on mosquito larvae. J Entomol Acarol Res 46: 107-111.

Wilhm JL. 1970. Range of diversity index in benthic macroinvertebrate populations. J Water Pollut Cont Fed 42 (5): 221-224.

WWF. 2016. Living Planet Report 2016: risk and resilience in a new era. WWF International, Gland, Switzerland.

Yang CM, Zettel H. 2005. Guide to the aquatic Heteroptera of Singapore and Peninsular Malaysia V. Hydrometridae. Raffles B Zool 53 (1): 79-97.

Yapo LM, Atse CB, Kouassi P. 2013. Composition, abundance and diversity of aquatic insects in fishponds of southern Ivory Coast, West Africa. Faunistic Entomol 66: 123-133.

Yule CM, Yong HS. 2004. Freshwater Invertebrates of the Malaysian Region. Academy of Sciences Malaysia, Kuala Lumpur. 
BIODIVERSITAS

Volume 21, Number 7, July 2020

Pages: 3047-3056
ISSN: 1412-033X

E-ISSN: 2085-4722

DOI: $10.13057 /$ biodiv/d210723 